Article

\title{
Organocatalytic Access to Enantioenriched Spirooxindole-Based 4-Methyleneazetidines
}

\author{
Giulia Rainoldi ${ }^{1}$, Matteo Faltracco ${ }^{2}$, Claudia Spatti ${ }^{1}$, Alessandra Silvani ${ }^{1, *}$ \\ and Giordano Lesma ${ }^{1}$ \\ 1 Department of Chemistry, University of Milan, via Golgi 19, 20133 Milan, Italy; \\ giulia.rainoldi@unimi.it (G.R.); claudia.spatti@studenti.unimi.it (C.S.); giordano.lesma@unimi.it (G.L.) \\ 2 Department of Chemistry \& Pharmaceutical Sciences, Amsterdam Institute of Molecules Medicines \& \\ Systems (AIMMS), Vrije Universiteit Amsterdam, De Boelelaan 1108, 1081 HZ Amsterdam, The Netherlands; \\ matteofaltracco92@gmail.com \\ * Correspondence: alessandra.silvani@unimi.it; Tel.: +39-025-031-4080
}

Received: 30 October 2017; Accepted: 17 November 2017; Published: 21 November 2017

\begin{abstract}
This work describes the synthesis of enantioenriched spiro compounds, incorporating the azetidine and the oxindole motifs. The preparation relies on a formal [2+2] annulation reaction of isatin-derived $\mathrm{N}$-tert-butylsulfonyl ketimines with allenoates. The asymmetric induction is secured by an organocatalytic strategy, exploiting a bifunctional cinchona-type $\beta$-isocupridine-based catalyst. Some post-transformation products, including unexpected spiropyrroline and 3,3-disubstituted oxindole derivatives, are also presented.
\end{abstract}

Keywords: spirooxindoles; organocatalysis; azetidines; cinchona-based catalysts

\section{Introduction}

Spirocyclic scaffolds are privileged in drug discovery, thanks to the conformational restriction imparted by the spiro carbon, which provides an excellent strategy to improve ligand-protein binding in many different therapeutic areas [1,2].

Among spirocycles, spirooxindoles are compounds characterized by the presence of a spiro ring fused at the $\mathrm{C} 3$ position of the oxindole core. A high number of them have been reported to exert various biological activities (i.e., antitumoral [3], anti-inflammatory [4] and antiviral [5]), quite often associated with a relevant target-specificity. The varied bioactivities of spirooxindoles are mainly distinguished by the kind of spiro ring fused at the $\mathrm{C} 3$ position, as well as by substituent moieties both on the spiro ring and on the oxindole scaffold. These structural elements lead to the diverse but relatively specific pharmacological profiles of this class of privileged molecules.

Owing to the therapeutic potential and, at the same time, to the synthetic challenge associated with spirooxindoles, there is a huge interest to develop new synthetic methodologies [6], in particular those achieving asymmetric induction by catalytic protocols $[7,8]$.

Since the most widely exploited scaffolds so far involve the spiro junction of oxindoles with five-membered and six-membered rings, we recently aimed to contribute to greater diversity in this field turning our attention to four membered rings. With the notable exception of $\beta$-lactams, four-membered rings have received limited attention from medicinal chemists until recently, with only a few spirocyclic azetidine scaffolds proposed as new potential lead compounds $[9,10]$.

In our ongoing work devoted to the asymmetric synthesis of spirooxindoles [11,12], we recently reported the first highly diastereoselective entry into chiral spirooxindole-based 4-methyleneazetidines [13]. Such compounds can be considered new lead structures in drug discovery and also versatile intermediates, thanks to the presence of the reactive carbon-carbon double bond and of the carboxylic ester moiety (Scheme 1a). 
As a continuation of this previous achievement, we have regarded the advantages of catalytic methods and faced the challenge of the catalytic asymmetric construction of such spirooxindole-based azetidine ring system.

Among catalytic methods, organocatalysis has brought unprecedented progress to the asymmetric construction of spirooxindoles [14] and 3-amino-2-oxindoles bearing tetra-substituted stereocenters $[15,16]$. It is especially attractive due to the general availability and stability of organocatalysts and mild and simple reaction conditions used.

The first asymmetric organocatalytic synthesis of 2,4-disubstituted azetidines was reported by Zhu et al. [17] in 2011 (Scheme 1b). It relies on the formal [2 + 2] cycloaddition of $N$-sulfonyl-aldimines and allenoates using a novel bifunctional quinidine derivative as catalyst. A variety of aromatic $N$-sulfonyl-aldimines underwent cycloaddition with allenoates to afford $R$-configured azetidines in good yields and good regio- and enantioselectivities. Two years later, Sasai et al. [18] presented the first example of an enantioselective organocatalytic cycloaddition of allenoates involving ketimines, and thus affording azetidines with a chiral tetrasubstituted carbon stereogenic center (Scheme 1b).

Starting from isatin-derived $N$-tert-butylsulfonyl ketimines, we considered their organocatalyzed, formal $[2+2]$ annulation reaction with allenoates as a high atom-economy strategy to obtain functionalized chiral spirooxindole-based 4-methyleneazetidines. Here we demonstrate the suitability of bifunctional cinchona alkaloids derivatives to promote such annulation, leading for the first time to enantioenriched azetidine-based spiro compounds by means of an organocatalytic method (Scheme 1c).

(a): our previous work

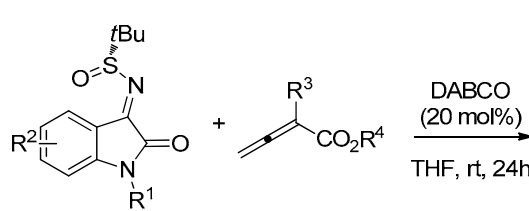

$\mathrm{R}^{1}$

(b): other authors' previous works

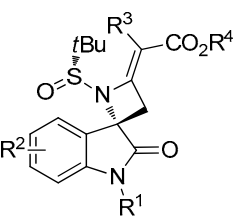

E-selectivity
dr $>99 \cdot 1$
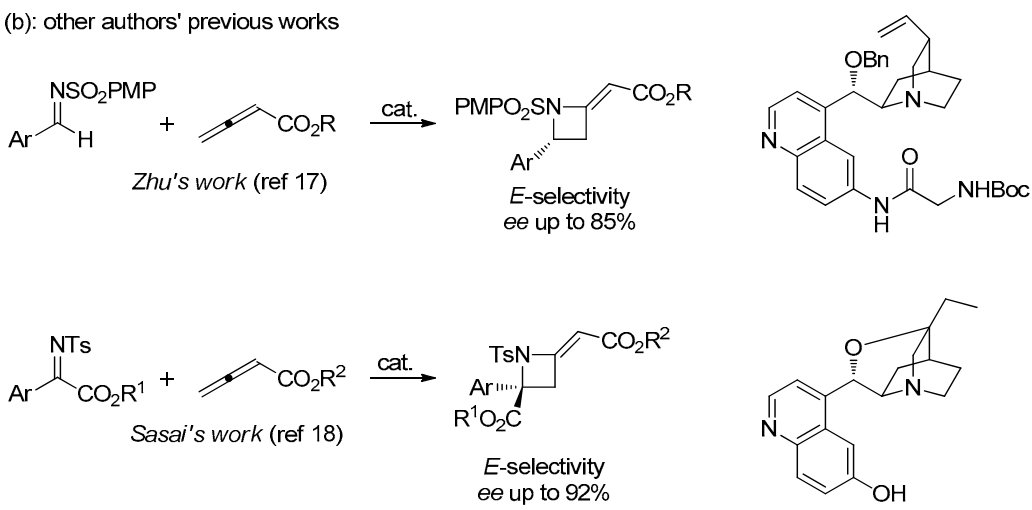

(c): this work
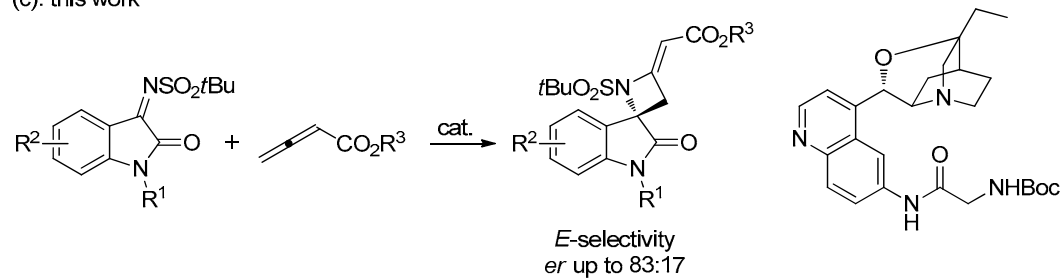

er up to $83: 17$

Scheme 1. (a) Our previous diastereoselective strategy to chiral spirooxindole-based 4-methyleneazetidines; (b) Reported organocatalyzed formal [2 + 2] cycloadditions of aldimmines and ketimines with allenoates; (c) Organocatalysed enantioselective strategy to chiral spirooxindole-based 4-methyleneazetidines. 


\section{Results and Discussion}

We started our investigation evaluating the reaction of ethyl buta-2,3-dienoate (4a) with different $N$-benzylisatin-derived ketimines [19], namely $N$-tert-butylsulfonyl imine 1a, $N$ - $p$-toluenesulfonyl imine 2 and $N$-Boc imine 3 (Table 1 ).

All substrates 1a, 2 and 3 afforded the corresponding azetidines 6a, 7 and 8 in presence of DABCO (entries 1-3). In the case of $N$-Boc ketimine 3, also the aza-Morita-Baylis-Hillman (AMBH) product 9 was isolated in low yield. Then the same ketimines 1a, 2 and $\mathbf{3}$ have been tested in the organocatalytic reaction, employing the quinidine-derived alkaloid $\beta$-isocupridine $(\beta$-ICD) catalyst 5a. Both $N$-tert-butylsulfonyl imine $1 \mathbf{a}$ and tosyl imine 2 afforded the expected azetidines $\mathbf{6 a}$ and 7 in good yield and enantiomeric ratio (er) (entries 4 and 5), whereas in this condition the $N$-Boc ketimine 3 provided only the AMBH product 9 (entry 6).

Table 1. Variation of the isatin-derived ketimines. ${ }^{a}$

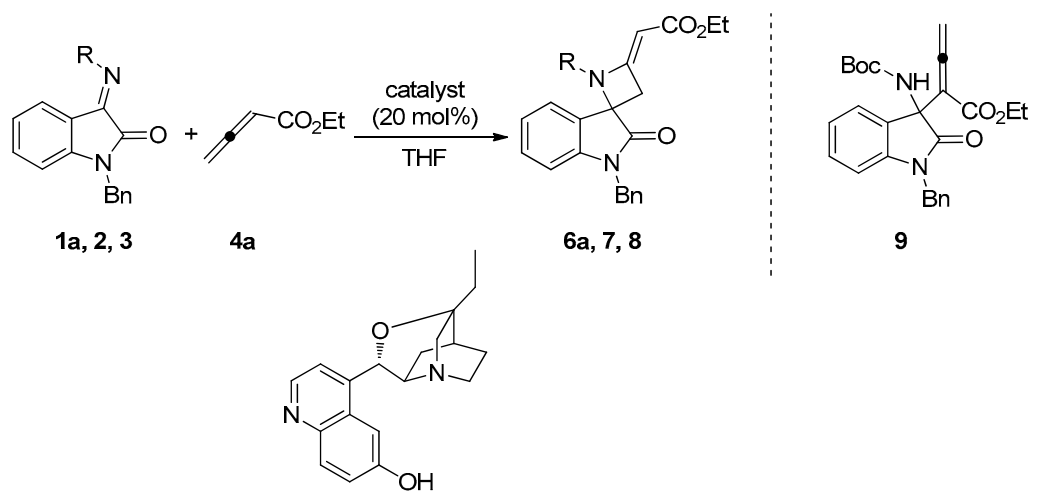

\begin{tabular}{ccccc}
\multicolumn{7}{c}{$\mathbf{a}$} \\
\hline Entry & Ketimine (R) & Catalyst & Product (Yield \%) & er $^{\boldsymbol{c}}$ \\
\hline 1 & $\mathbf{1 a}\left(\mathrm{SO}_{2} t \mathrm{Bu}\right)$ & $\mathbf{D A B C O}$ & $\mathbf{6 a}(90)$ & - \\
2 & $\mathbf{2}(\mathrm{Ts})$ & DABCO & $\mathbf{7}(77)$ & - \\
3 & $\mathbf{3}(\mathrm{Boc})$ & $\mathbf{D A B C O}$ & $\mathbf{8}(48), \mathbf{9}(28)$ & - \\
4 & $\mathbf{1 a}\left(\mathrm{SO}_{2} t \mathrm{Bu}\right)$ & $\mathbf{5 a}$ & $\mathbf{6 a}(91)$ & $70: 30$ \\
5 & $\mathbf{2}(\mathrm{Ts})$ & $\mathbf{5 a}$ & $\mathbf{7}(80)$ & $61: 39$ \\
6 & $\mathbf{3}(\mathrm{Boc})$ & $\mathbf{5 a}$ & $\mathbf{9}(52)$ & - \\
\hline
\end{tabular}

\footnotetext{
${ }^{a}$ Reaction conditions: ketimine $(0.15 \mathrm{mmol})$, allenoate $4 \mathrm{a}(0.30 \mathrm{mmol})$ and catalyst $(0.030 \mathrm{mmol}) \mathrm{in} \mathrm{THF}(1.5 \mathrm{~mL})$ at room temperature; ${ }^{b}$ Isolated yields, after purification by column chromatography on silica gel; ${ }^{c}$ Determined by HPLC, on a chiral stationary phase.
}

N-tert-Butylsulfonyl imine 1a was selected for further optimization of the reaction conditions, as reported in Table 2. Starting our screening testing different catalysts, we observed that typical quinidine-derived catalysts $\mathbf{5 b} \mathbf{b} \mathbf{f}$ were unable to promote the reaction, even after prolonged reaction times (entries 1-5). In all cases only degradation of the starting ketimine was observed. Instead, using $\beta$-isocupridine-based catalysts $5 \mathbf{g}-1$, the desired azetidine $\mathbf{6 a}$ was obtained in all cases, with the exception of reaction with catalyst $5 \mathrm{~h}$ (entries 6-12).

The high conformational bias of $\beta$-ICD and its derivatives, as well as the presence of at least a hydrogen bond donor group at the $\mathrm{C} 6$ position of the quinoline ring, seem to be necessary requirements to coordinate the substrate and therefore to catalyse the reaction. Best results in terms of both er and chemical yield have been obtained employing catalyst $\mathbf{5 g}$, which was then used for a further screening of solvents and temperature.

Performing the reaction in apolar solvents such as dichloromethane and toluene, the desired product was observed just in very low yields (entries 13 and 14). Lowering the temperature to $0{ }^{\circ} \mathrm{C}$ no appreciable improvement of er was observed and prolonged reaction time was needed to obtain the desired azetidine in good yield (entry 15). At $-20^{\circ} \mathrm{C}$ the reaction was completely stopped (entry 16). 
Finally, on reducing the catalyst amount (entry 17) no improved er was observed, but just extension of the reaction time with a reduction of the chemical yield.

Table 2. Catalyst and solvent screen for the reaction of $N$-tert-butylsulfonyl imine 1a with ethyl buta-2,3-dienoate (4a). ${ }^{a}$

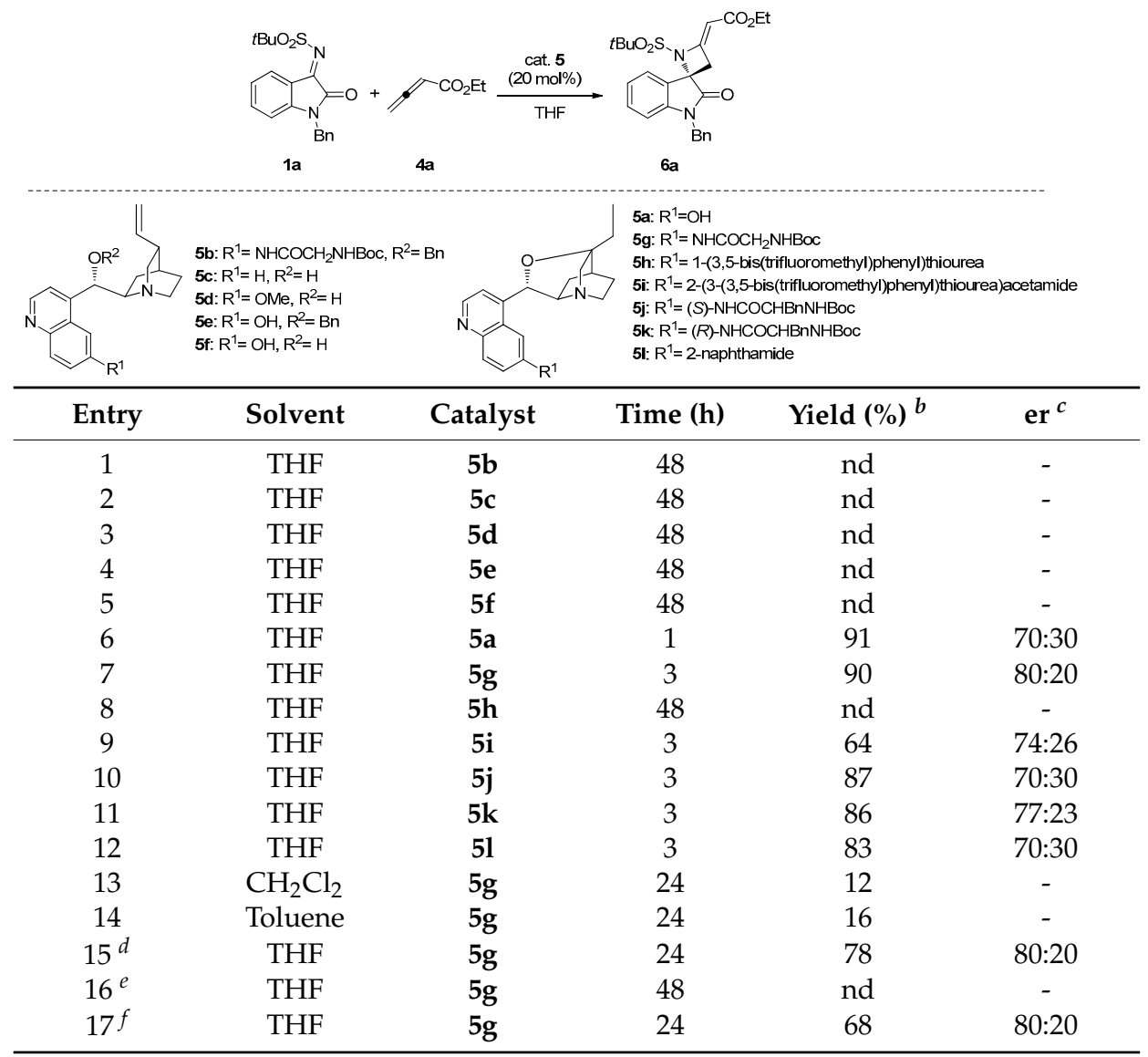

${ }^{a}$ Reaction conditions: ketimine $1 \mathbf{a}(0.15 \mathrm{mmol}), \mathbf{4 a}(0.30 \mathrm{mmol})$ and catalyst $(0.03 \mathrm{mmol})$ in solvent $(1.5 \mathrm{~mL})$ at room temperature, unless otherwise noted; ${ }^{b}$ Isolated yields, after purification by column chromatography on silica gel; ${ }^{c}$ Determined by HPLC, on a chiral stationary phase; ${ }^{d}$ Reaction performed at $0{ }^{\circ} \mathrm{C} ;{ }^{e}$ Reaction performed at $-20{ }^{\circ} \mathrm{C}$;

$f$ Catalyst loading $10 \%$ mol. nd $=$ not detected.

With the best conditions in hand, we planned to screen $N$-tert-butylsulfonyl ketimines bearing different $N$-substituents at the oxindole ring (1b-f, Scheme 2$)$. Such starting compounds have been prepared by $m$-chloroperbenzoic acid-mediated oxidation of the corresponding $N$-tert-butylsulfinyl ketimines and immediately used without purification (see Materials and Methods for the general synthetic procedure).

Generally, good yields and er were observed in the reaction with allenoate $4 \mathbf{a}$, under the catalysis of $5 \mathrm{~g}$. The presence of the bulky trityl substituent at the oxindole nitrogen led to the corresponding spiroazetidine derivative $\mathbf{6 c}$ with the best yield, but with the lowest enantioselectivity. The best result in terms of er was obtained performing the reaction with $N$-methyl substituted ketimine $\mathbf{1} \mathbf{b}$, leading to product $\mathbf{6 b}$.

Depending on whether electron-withdrawing or electron-donating group was introduced at 4-, 5or 6-position of the benzene ring of starting ketimines $(\mathbf{1 g}-\mathbf{j})$, the reactions proceeded in a different way. Good yield and enatioselectivity were observed for the synthesis of 5-OMe substituted spiroazetidine 6g. In the presence of the electron withdrawing $\mathrm{Cl}$-substituent at $\mathrm{C} 5$ position, a very low yield was achieved (6h). Finally, compounds $\mathbf{6} \mathbf{i}$ and $\mathbf{6 j}$ were not detected in the crude, but just degradation of the ketimine starting material was observed. 
At the end, we investigated the formal [2 + 2] annulation with a different allenoate. Considering the possibility of a favourable $\pi-\pi$ interaction with the aromatic portion of the catalyst, we selected benzyl buta-2,3-dienoate $\mathbf{4 b}$. Indeed, the corresponding azetidine $\mathbf{6 k}$ could be easily obtained in good yield, even if in quite similar er.

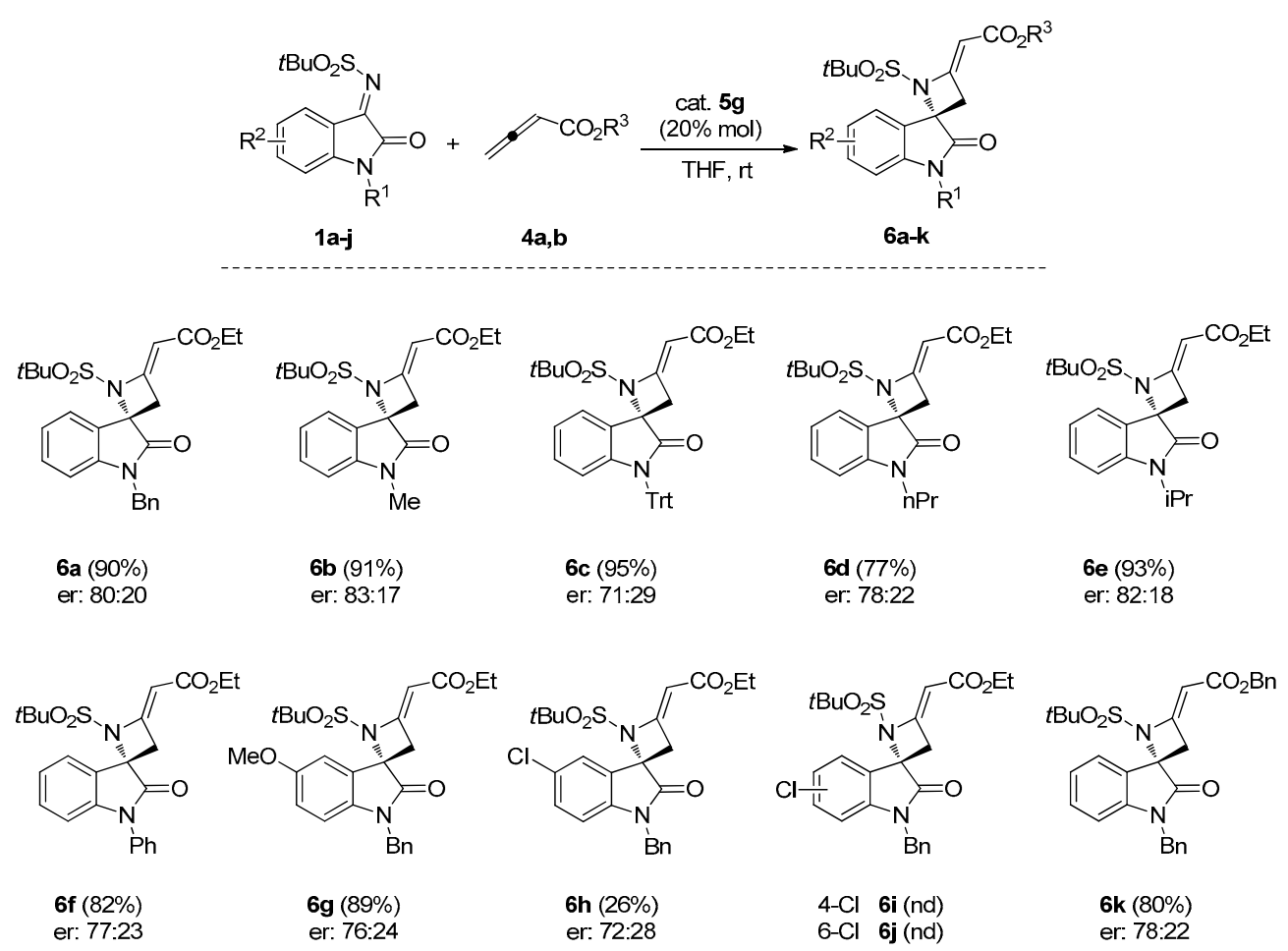

Scheme 2. Substrate scope for the reaction of various ketimines $\mathbf{1 a}-\mathbf{j}$ with allenoates $\mathbf{4 a}, \mathbf{b}$, catalyzed by catalyst $\mathbf{5 g}$. Reactions conditions: ketimine $\mathbf{1 a}-\mathbf{j}(0.15 \mathrm{mmol}), \mathbf{4 a}, \mathbf{b}(0.30 \mathrm{mmol}), \mathbf{5 g}(0.03 \mathrm{mmol})$ in THF (1.5 mL). Isolated yields, after purification by column chromatography on silica gel, are reported. Er was determined by HPLC, on a chiral stationary phase. Trt = Trityl; nd = not detected.

The absolute configuration of the major enantiomer of compound 6a was determined through chemical correlation, exploiting a proper conversion of reference compound I [13] (Scheme 3). More precisely, performing a selective sulfur oxidation, enantiopure compound $\mathbf{6} \mathbf{a}^{\prime}$ could be easily obtained from compound I. Relying on comparison of both optical rotation signs and chiral HPLC chromatograms, the (S)-configuration at the quaternary stereocenter of product 6a could be assigned with certainty.

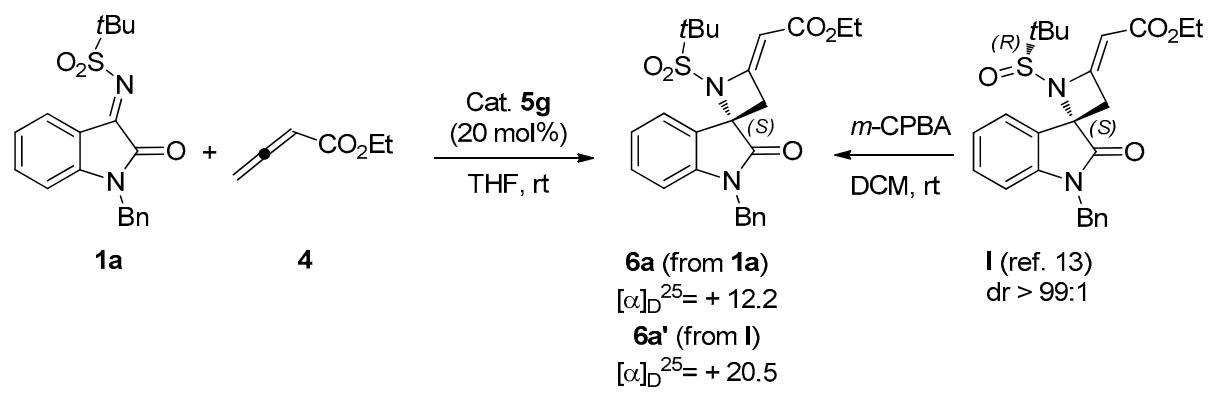

Scheme 3. Chemical correlation for the assignment of absolute configuration of compound $6 \mathbf{a}$. For comparison of the chiral HPLC chromatograms of $\mathbf{6 a}$ and $\mathbf{6} \mathbf{a}^{\prime}$, see the Supporting Information. 
To rationalize the stereochemical outcome, we referred to the proposed mechanism for similar cinchona-base catalysed [2 +2$]$ annulation reactions [17]. Accordingly, the basic quinuclidine moiety acts as a nucleophile activator, producing a zwitterionic allylic carbanion from the allenoate reagent. The activated g-position of this intermediate undergoes addition to the ketimine, followed by an intramolecular attack back from ketimine's nitrogen, leading to the azetidine ring and catalyst's regeneration. From our experimental data, it results that the peculiar skeleton of $\beta$-ICD-type catalysts (e.g., $\mathbf{5 g}$ ), more rigid with respect to that of corresponding quinidine-catalysts (e.g., $5 \mathbf{b}$ ), seems the only able to bring reactants to the correct distance for a productive reaction.

Moreover, the presence of the $\mathrm{N}$-Boc glycinamide unit at $\mathrm{C}^{\prime}$ position in catalyst $\mathbf{5 g}$ ensures a proper activation of the ketimine, through up to two hydrogen bonds. Relying on this disposition, to minimize the steric hindrance with the catalyst's residue, ketimine offers its Re-face to the incoming $\gamma$-carbanion, leading to the corresponding spiroazetidine derivative in the prevailing $(S)$-configuration at the $\mathrm{C} 3$ of the oxindole ring. On this basis, a plausible transition state for the reported reaction is illustrated in Scheme 4, where ketimine $\mathbf{1 b}$ is shown coordinated to the catalyst $\mathbf{5 g}$ by double $\mathrm{H}$-bonding, so explaining the found superiority of the amide $\mathrm{N}-\mathrm{H}$ over the $\mathrm{O}-\mathrm{H}$ group in this kind of process.

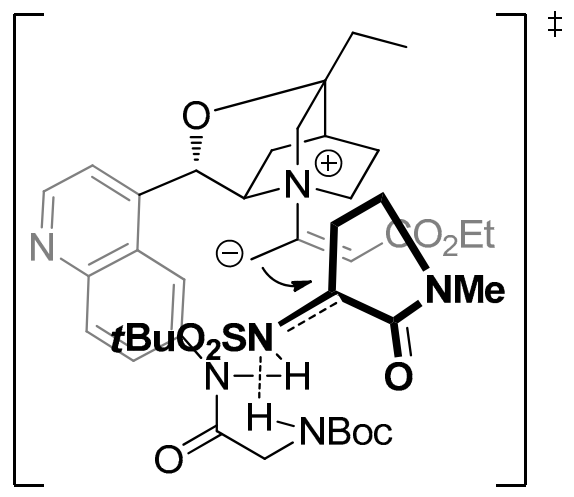

attack on the ketimine Re-face<smiles>CCOC(=O)/C=C1\C[C@@]2(C(=O)N(C)c3ccccc32)N1S(=O)(=O)c1ccccc1</smiles>

6b (major enantiomer) (er: 83:17)

Scheme 4. Possible transition state for reaction of ketimine $\mathbf{1 b}$ with allenoate $\mathbf{4 a}$, under catalysis of $\mathbf{5 g}$. Ketimine $\mathbf{1 b}$ is reported without the condensed phenyl ring for clarity.

To demonstrate the synthetic utility of obtained compounds, some reactions of $\mathbf{6 a}$ have been performed (Scheme 5). Thus, acid 7 could be quantitatively obtained by reaction with LiOH. Aiming to selectively remove the tert-butylsulfonyl group, we refer to a milestone literature procedure [20], reporting the cleavage of such protecting groups to the parent amines by mild acidic solvolysis. Surprisingly, exposure of $\mathbf{6 a}$ to $0.075 \mathrm{~N} \mathrm{TfOH} / \mathrm{CH}_{2} \mathrm{Cl}_{2}$ at $0{ }^{\circ} \mathrm{C}$ for two hours afforded quantitatively the rearranged product 8 , without trace of the expected spiroazetidine $\mathrm{N}$-deprotected derivative. The spiropyrroline ring system of compound $\mathbf{8}$ was disclosed by careful analysis of mono- and bidimensional NMR spectra. In particular, the Heteronuclear Multiple Bond Correlation (HMBC) experiment allowed a complete and safe assignment of all ${ }^{1} \mathrm{H}$ - and ${ }^{13} \mathrm{C}-\mathrm{NMR}$ signals. Changing the acid to trifluoroacetic acid (TFA) and adding anisole as scavenger, the reaction followed a different course, affording the unprecedented 3-tert-butylsulfonylamino, 3-substituted derivative $\mathbf{9}$, as the result of the acid catalyzed azetidine ring opening. Evidently, the presence of the ethoxycarbonylmethylene substituent in compound 6a diverts from the expected cleavage of the tert-butylsulfonyl group, addressing the reaction toward less predictable pathways. Anyway, preserving the integrity at the oxindole C 3 stereogenic centre, compounds $\mathbf{8}$ and $\mathbf{9}$ can be considered relevant examples of almost unexplored spiro and 3,3-disubstituted oxindole derivatives. 


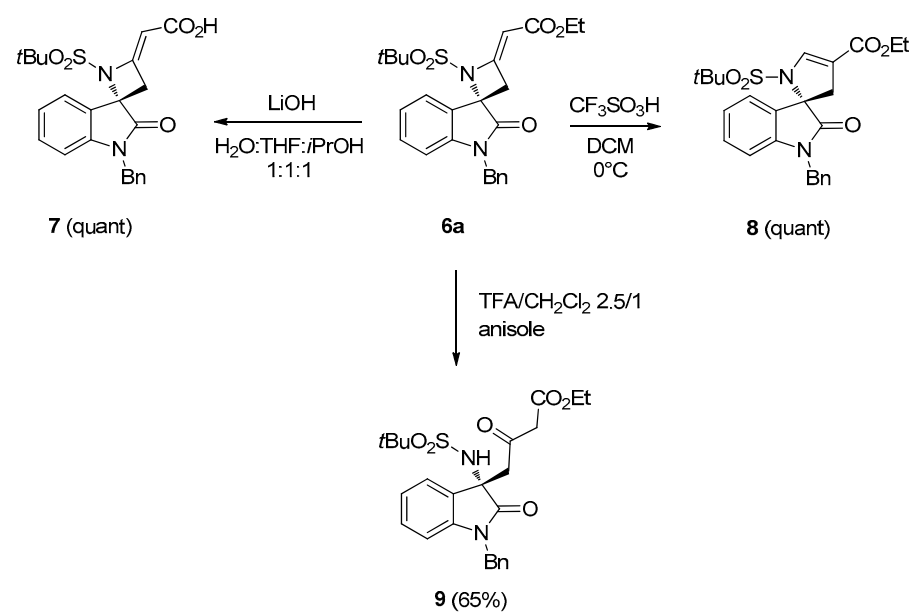

Scheme 5. Reactions performed from compound $6 \mathbf{a}$.

\section{Materials and Methods}

\subsection{General Experimental Procedures}

All commercial materials (Aldrich, Fluka, St. Louis, MO, USA) were used without further purification. All solvents were of reagent grade or HPLC grade. All reactions were carried out under a nitrogen atmosphere unless otherwise noted. All reactions were monitored by thin layer chromatography (TLC) on precoated silica gel 60 F254; spots were visualized with UV light or by treatment with ninhydrin solution in ethanol. Products were purified by flash chromatography (FC) on silica gel 60 (230-400 mesh). ${ }^{1} \mathrm{H}-\mathrm{NMR}$ spectra and ${ }^{13} \mathrm{C}-\mathrm{NMR}$ spectra were recorded on 300 and $400 \mathrm{MHz}$ spectrometers (AVANCE, Bruker, Billerica, MA, USA). Chemical shifts are reported in parts per million relative to the residual solvent. Multiplicities in ${ }^{1} \mathrm{H}-\mathrm{NMR}$ are reported as follows: $\mathrm{s}=$ singlet, $\mathrm{d}=$ doublet, $\mathrm{t}=$ triplet, $\mathrm{m}=$ multiplet, $\mathrm{br} \mathrm{s}=$ broad singlet. ${ }^{13} \mathrm{C}-\mathrm{NMR}$ spectra have been recorded using the APT pulse sequence. The number of carbons reported in the ${ }^{13} \mathrm{C}$ data are derived from Heteronuclear Multiple Bond Correlation (HMBC) experiments. High-resolution MS spectra were recorded with a Micromass Q-ToF micro TM mass spectrometer (Waters, Milford, MA, USA), equipped with an ESI source. Chiral HPLC analysis was performed on a PU-2080 system (JASCO Europe, Cremella (LC), Italy) (UV Detector and binary HPLC pump) at $254 \mathrm{~nm}$. Chiralcel AD columns were purchased from Daicel Chemical Industries ${ }^{\circledR}$ (Osaka, Japan). Optical rotator power $[\alpha]_{\mathrm{T}}^{\mathrm{D}}$ was measured with a Jasco P-1030 polarimeter, equipped with a cell of $1 \mathrm{dm}$ path length and $1 \mathrm{~mL}$ capacity. The light used has a wavelength of $589 \mathrm{~nm}$ (sodium D line).

\subsubsection{General Procedure for the Synthesis of N-tert-Butylsulfonyl Ketimines 1a-j}

To a solution of $\mathrm{N}$-substituted isatin $(1.17 \mathrm{mmol}, 1.0 \mathrm{eq})$ in anhydrous $\mathrm{CH}_{2} \mathrm{Cl}_{2}(2.9 \mathrm{~mL}, 0.4 \mathrm{M})$, $\mathrm{Ti}(\mathrm{OiPr})_{4}$ (2.34 mmol, $\left.2.0 \mathrm{eq}\right)$ and 2-methyl-2-propanesulfinamide (1.4 mmol, $\left.1.2 \mathrm{eq}\right)$ were added. The solution was refluxed until complete disappearance of the starting materials (monitored by TLC). The reaction was quenched by adding saturated aq. $\mathrm{NaHCO}_{3}(15 \mathrm{~mL})$ and diluted with $\mathrm{CH}_{2} \mathrm{Cl}_{2}$ $(15 \mathrm{~mL})$. The biphasic solution was filtered through a pad of Celite and the organic phase washed with water $(2 \times 15 \mathrm{~mL})$, dried over $\mathrm{Na}_{2} \mathrm{SO}_{4}$ and the solvent was evaporated under reduced pressure. The crude was purified by flash chromatography (FC), using hexane/EtOAc $/ \mathrm{CH}_{2} \mathrm{Cl}_{2}$ (gradient from 9:1:10 to $5 / 5 / 10$ ) as eluent.

New compounds:

(E)-N-(1-Propyl-2-oxoindolin-3-ylidene)-2-methylpropane-2-sulfinamide. Prepared starting from N-1-propylisatin. Orange foam, yield: $82 \% .{ }^{1} \mathrm{H}-\mathrm{NMR}\left(300 \mathrm{MHz}, \mathrm{CDCl}_{3}\right) \delta 8.37(\mathrm{~m}, \mathrm{br}, 1 \mathrm{H}), 7.41(\mathrm{t}, J=7.8 \mathrm{~Hz}, 1 \mathrm{H}), 7.02$ $(\mathrm{t}, J=7.8 \mathrm{~Hz}, 1 \mathrm{H}), 6.79(\mathrm{~d}, J=7.8 \mathrm{~Hz}, 1 \mathrm{H}), 3.66(\mathrm{t}, J=7.4 \mathrm{~Hz}, 2 \mathrm{H}), 1.70(\mathrm{sext}, J=7.5 \mathrm{~Hz}, 2 \mathrm{H}), 1.38$ 
$(\mathrm{s}, 9 \mathrm{H}), 0.96(\mathrm{t}, J=7.4 \mathrm{~Hz}, 3 \mathrm{H}) ;{ }^{13} \mathrm{C}-\mathrm{NMR}\left(101 \mathrm{MHz}, \mathrm{CDCl}_{3}\right) \delta 161.0,148.9,144.2,136.1,124.9,123.9(2 \mathrm{C})$, 109.9, 54.1, 42.5, 23.8 (3C), 21.3, 12.0; HRMS (ESI): $[\mathrm{M}+\mathrm{Na}]^{+}$, Calcd. for $\mathrm{C}_{15} \mathrm{H}_{20} \mathrm{~N}_{2} \mathrm{NaO}_{2} \mathrm{~S}^{+}$315.1138, found 315.1142 .

(E)-N-(1-Isopropyl-2-oxoindolin-3-ylidene)-2-methylpropane-2-sulfinamide. Prepared starting from $\mathrm{N}$-isopropylisatin. Orange foam, yield: $88 \%$. ${ }^{1} \mathrm{H}-\mathrm{NMR}\left(300 \mathrm{MHz}, \mathrm{CDCl}_{3}\right) \delta 8.40(\mathrm{~m}, \mathrm{br}, 1 \mathrm{H}), 7.41$ $(\mathrm{t}, J=7.8 \mathrm{~Hz}, 1 \mathrm{H}), 7.03(\mathrm{t}, J=7.8 \mathrm{~Hz}, 1 \mathrm{H}), 6.93(\mathrm{~d}, J=7.7 \mathrm{~Hz}, 1 \mathrm{H}), 4.50($ hept $J=6.8 \mathrm{~Hz}, 1 \mathrm{H}), 1.50$ $(\mathrm{d}, J=6.8 \mathrm{~Hz}, 6 \mathrm{H}), 1.39(\mathrm{~s}, 9 \mathrm{H}) ;{ }^{13} \mathrm{C}-\mathrm{NMR}\left(101 \mathrm{MHz}, \mathrm{CDCl}_{3}\right) \delta 162.3,148.3,143.9,136.0,123.8,123.6(2 \mathrm{C})$, 110.9, 55.9, 45.4, 23.7 (3C), 22.8 (2C); HRMS (ESI): [M + Na] ${ }^{+}$, Calcd. for $\mathrm{C}_{15} \mathrm{H}_{20} \mathrm{~N}_{2} \mathrm{NaO}_{2} \mathrm{~S}^{+} 315.1138$, found 315.1147 .

(E)-2-Methyl-N-(2-oxo-1-phenylindolin-3-ylidene)propane-2-sulfinamide. Prepared starting from $\mathrm{N}$-phenylisatin. Orange foam, yield: 76\%. ${ }^{1} \mathrm{H}-\mathrm{NMR}\left(300 \mathrm{MHz}, \mathrm{CDCl}_{3}\right) \delta 8.46(\mathrm{~m}, \mathrm{br}, 1 \mathrm{H}), 7.54$ $(\mathrm{t}, J=7.6 \mathrm{~Hz}, 2 \mathrm{H}), 7.49-7.33(\mathrm{~m}, 4 \mathrm{H}), 7.10(\mathrm{t}, J=7.8 \mathrm{~Hz}, 1 \mathrm{H}), 6.80(\mathrm{~d}, J=7.8 \mathrm{~Hz}, 1 \mathrm{H}), 1.43(\mathrm{~s}, 9 \mathrm{H})$; ${ }^{13}$ C-NMR (101 MHz, CDCl3) $\delta$ 158.2, 152.3, 149.4, 136.1, 133.9, 130.5 (3C), 129.3 (2C), 127.0, 124.9, 124.7, 111.1, 55.9, 23.9 (3C); HRMS (ESI): [M + Na] ${ }^{+}$, Calcd. for $\mathrm{C}_{18} \mathrm{H}_{18} \mathrm{~N}_{2} \mathrm{NaO}_{2} \mathrm{~S}^{+}$349.0981, found 349.0989.

To a solution of the desired sulfinamide in $\mathrm{CH}_{2} \mathrm{Cl}_{2}(6 \mathrm{~mL}), m-\mathrm{CPBA}(1.5 \mathrm{eq})$ was slowly added at room temperature and the mixture was stirred until completion of the reaction (monitored by TLC). The reaction was quenched by adding saturated aq. $\mathrm{NaHCO}_{3}(15 \mathrm{~mL})$ and diluted with $\mathrm{CH}_{2} \mathrm{Cl}_{2}(15 \mathrm{~mL})$. The organic phase was washed with sat. $\mathrm{NaHCO}_{3}(2 \times 40 \mathrm{~mL})$, dried $\left(\mathrm{Na}_{2} \mathrm{SO}_{4}\right)$, and concentrated. The corresponding sulfonamide was used without further purification. New compounds:

(E)-2-Methyl-N-(2-oxo-1-tritylindolin-3-ylidene)propane-2-sulfonamide (1c). Red foamy solid, yield: 97\%. ${ }^{1} \mathrm{H}-\mathrm{NMR}\left(300 \mathrm{MHz}, \mathrm{CDCl}_{3}\right) \delta 8.42(\mathrm{~d}, J=7.7 \mathrm{~Hz}, 1 \mathrm{H}), 7.49-7.37(\mathrm{~m}, 6 \mathrm{H}), 7.37-7.19(\mathrm{~m}, 9 \mathrm{H}), 7.11$ $(\mathrm{t}, J=7.8 \mathrm{~Hz}, 1 \mathrm{H}), 6.97(\mathrm{~d}, J=7.8 \mathrm{~Hz}, 1 \mathrm{H}), 6.35(\mathrm{~d}, J=7.8 \mathrm{~Hz}, 1 \mathrm{H}), 1.44(\mathrm{~s}, 9 \mathrm{H}) ;{ }^{13} \mathrm{C}-\mathrm{NMR}(101 \mathrm{MHz}$, $\left.\mathrm{CDCl}_{3}\right) \delta 162.1,151.5,144.5,141.7$ (3C), 136.9, 130.1 (6C), 128.6 (6C), 128.0 (3C), 123.9, 123.8, 117.9, 114.9, 75.9, 60.7, 24.5 (3C); HRMS (ESI): [M + Na] ${ }^{+}$, Calcd. for $\mathrm{C}_{31} \mathrm{H}_{28} \mathrm{~N}_{2} \mathrm{NaO}_{3} \mathrm{~S}^{+}$531.1716, found 531.1709.

(E)-2-Methyl-N-(2-oxo-1-propylindolin-3-ylidene)propane-2-sulfonamide (1d). Red foamy solid, yield: 95\%. ${ }^{1} \mathrm{H}-\mathrm{NMR}\left(300 \mathrm{MHz}, \mathrm{CDCl}_{3}, 7: 3\right.$ mixture of two rotamers) $\delta 8.40(\mathrm{~m}, \mathrm{br}, 0.3 \mathrm{H}), 8.06(\mathrm{~d}, J=7.8 \mathrm{~Hz}, 0.7 \mathrm{H})$, $7.50(\mathrm{t}, J=7.8 \mathrm{~Hz}, 0.3 \mathrm{H}), 7.45(\mathrm{t}, J=7.8 \mathrm{~Hz}, 0.7 \mathrm{H}), 7.11(\mathrm{t}, J=7.8 \mathrm{~Hz}, 0.7 \mathrm{H}), 7.07(\mathrm{t}, J=7.8 \mathrm{~Hz}, 0.3 \mathrm{H})$, $6.93(\mathrm{~d}, J=7.8 \mathrm{~Hz}, 0.7 \mathrm{H}), 6.82(\mathrm{t}, J=7.8 \mathrm{~Hz}, 0.3 \mathrm{H}), 3.74-3.62(\mathrm{~m}, 2 \mathrm{H}), 1.74(\mathrm{sext}, \mathrm{br}, J=6.8 \mathrm{~Hz}, 2 \mathrm{H})$, $1.62(\mathrm{~s}, 6.3 \mathrm{H}), 1.60(\mathrm{~s}, 2.7 \mathrm{H}), 0.99(\mathrm{t}, \mathrm{br}, J=6.8 \mathrm{~Hz}, 3 \mathrm{H}) ;{ }^{13} \mathrm{C}-\mathrm{NMR}\left(75 \mathrm{MHz}, \mathrm{CDCl}_{3}\right) \delta 162.6,150.4,147.4$, 139.0 and $138.5(1 \mathrm{C}), 124.0(2 \mathrm{C}), 116.2,110.4$ and $110.3(1 \mathrm{C}), 60.6,43.1$ and $42.7(1 \mathrm{C}), 24.5(3 \mathrm{C}), 21.2$ and 20.8 (1C), 12.0; HRMS (ESI): [M + Na] ${ }^{+}$, Calcd. for $\mathrm{C}_{15} \mathrm{H}_{20} \mathrm{~N}_{2} \mathrm{NaO}_{3} \mathrm{~S}^{+}$331.1087, found 331.1096.

(E)-2-(1-Isopropyl-2-oxoindolin-3-ylidene)-2-methylpropane-2-sulfonamide (1e). Red foamy solid, yield: 99\%. ${ }^{1} \mathrm{H}-\mathrm{NMR}\left(400 \mathrm{MHz}, \mathrm{CDCl}_{3}, 17: 3\right.$ mixture of two rotamers) $\delta 8.19$ (dd, $J=7.8$ and $\left.1.7 \mathrm{~Hz}, 0.15 \mathrm{H}\right), 8.12$ $(\mathrm{dd}, J=7.8$ and $1.7 \mathrm{~Hz}, 0.85 \mathrm{H}), 7.76(\mathrm{ddd}, J=8.2,7.5$ and $1.7 \mathrm{~Hz}, 0.15 \mathrm{H}), 7.73(\mathrm{ddd}, J=8.2,7.5$ and $1.7 \mathrm{~Hz}, 0.85 \mathrm{H}), 7.34-7.21(\mathrm{~m}, 2 \mathrm{H}), 4.77$ (hept, $J=6.8 \mathrm{~Hz}, 1 \mathrm{H}), 1.62(\mathrm{~d}, J=6.9 \mathrm{~Hz}, 6 \mathrm{H}), 1.62(\mathrm{~s}, 1.35 \mathrm{H}) 1.57$ $(\mathrm{s}, 7.65 \mathrm{H}) ;{ }^{13} \mathrm{C}-\mathrm{NMR}\left(101 \mathrm{MHz}, \mathrm{CDCl}_{3}\right) \delta 162.6,158.0,149.9,138.9$ and $138.5(1 \mathrm{C}), 124.9$ and $124.7(1 \mathrm{C})$, 124.0 and $123.7(1 \mathrm{C}), 113.3,112.0$ and $111.3(1 \mathrm{C}), 60.0,45.7$ and $45.5(1 \mathrm{C}), 24.7$ and 24.5 (3C), 19.9 (2C); HRMS (ESI): $[\mathrm{M}+\mathrm{Na}]^{+}$, Calcd. for $\mathrm{C}_{15} \mathrm{H}_{20} \mathrm{~N}_{2} \mathrm{NaO}_{3} \mathrm{~S}^{+} 331.1087$, found 331.1081.

(E)-2-Methyl-N-(2-oxo-1-phenylindolin-3-ylidene)propane-2-sulfonamide (1f). Red foamy solid, yield: 98\%. ${ }^{1} \mathrm{H}-\mathrm{NMR}\left(400 \mathrm{MHz}, \mathrm{CDCl}_{3}, 7: 3\right.$ mixture of two rotamers) $\delta 8.21(\mathrm{dd}, J=7.9$ and $1.4 \mathrm{~Hz}, 0.7 \mathrm{H}$ ), $8.00(\mathrm{~d}, \mathrm{br}, J=7.9 \mathrm{~Hz}, 0.3 \mathrm{H}), 7.69-7.53(\mathrm{~m}, 4 \mathrm{H}), 7.44(\mathrm{t}, J=7.8 \mathrm{~Hz}, 0.3 \mathrm{H}), 7.41-7.26(\mathrm{~m}, 2.7 \mathrm{H}), 6.58$ $(\mathrm{d}, J=7.8 \mathrm{~Hz}, 1 \mathrm{H}), 1.47(\mathrm{~s}, 9 \mathrm{H}) ;{ }^{13} \mathrm{C}-\mathrm{NMR}\left(101 \mathrm{MHz}, \mathrm{CDCl}_{3}\right) \delta 162.2,150.9,143.1,138.5$ and $137.5(1 \mathrm{C})$, 133.7, 130.6 (3C), 129.6 and 129.5 (2C), 127.1, 125.0 and 124.7 (1C), 115.9, 111.4, 60.8, 24.9-24.5 (3C); HRMS (ESI): $[\mathrm{M}+\mathrm{Na}]^{+}$, Calcd. for $\mathrm{C}_{18} \mathrm{H}_{18} \mathrm{~N}_{2} \mathrm{NaO}_{3} \mathrm{~S}^{+} 365.0930$, found 365.0939.

(E)-N-(1-Benzyl-5-methoxy-2-oxoindolin-3-ylidene)-2-methylpropane-2-sulfonamide (1g). Red foamy solid, yield: 98\%. ${ }^{1} \mathrm{H}-\mathrm{NMR}\left(400 \mathrm{MHz}, \mathrm{CDCl}_{3}\right) \delta 7.42-7.26(\mathrm{~m}, 6 \mathrm{H}), 6.99(\mathrm{dd}, J=8.2$ and $2.6 \mathrm{~Hz}, 1 \mathrm{H}), 6.62$ 
$(\mathrm{d}, J=8.3 \mathrm{~Hz}, 1 \mathrm{H}), 4.89(\mathrm{~s}, 2 \mathrm{H}), 3.79(\mathrm{~s}, 3 \mathrm{H}), 1.64(\mathrm{~s}, 9 \mathrm{H}) ;{ }^{13} \mathrm{C}-\mathrm{NMR}\left(101 \mathrm{MHz}, \mathrm{CDCl}_{3}\right) \delta 162.7,156.7$, 145.2, 144.1, 135.3, 129.7 (2C), 128.8, 128.0 (2C), 126.7, 125.6, 116.7, 111.9, 60.7, 56.7, 44.9, 24.6 (3C); HRMS (ESI): [M + Na] $]^{+}$, Calcd. for $\mathrm{C}_{20} \mathrm{H}_{22} \mathrm{~N}_{2} \mathrm{NaO}_{4} \mathrm{~S}^{+}$409.1192, found 409.1186.

(E)-N-(1-Benzyl-5-chloro-2-oxoindolin-3-ylidene)-2-methylpropane-2-sulfonamide (1h). Red foamy solid, yield: $92 \%$. ${ }^{1} \mathrm{H}-\mathrm{NMR}\left(400 \mathrm{MHz}, \mathrm{CDCl}_{3}, 4: 1\right.$ mixture of two rotamers) $\delta 7.42-7.26(\mathrm{~m}, 7 \mathrm{H}), 6.76$ $(\mathrm{d}, J=8.2 \mathrm{~Hz}, 0.2 \mathrm{H}), 6.68(\mathrm{~d}, J=8.2 \mathrm{~Hz}, 0.8 \mathrm{H}), 4.93(\mathrm{~s}, 2 \mathrm{H}), 1.67(\mathrm{~s}, 1.8 \mathrm{H}), 1.65(\mathrm{~s}, 7.2 \mathrm{H}) ;{ }^{13} \mathrm{C}-\mathrm{NMR}$ $\left(101 \mathrm{MHz}, \mathrm{CDCl}_{3}\right) \delta 161.2,148.2,145.6,138.3$ and 137.9 (1C), 134.7, 130.7 and $129.8(2 \mathrm{C}), 129.9,129.0$ (2C), 128.0 (2C), 116.9, 112.2, 63.9, 45.5 and 45.0 (1C), 24.6 and 24.5 (3C); HRMS (ESI): [M + Na] ${ }^{+}$, Calcd. for $\mathrm{C}_{19} \mathrm{H}_{19} \mathrm{ClN}_{2} \mathrm{NaO}_{3} \mathrm{~S}^{+}$413.0697, found 413.0674.

\subsubsection{General Procedure for the Synthesis of Spiroazetidines $\mathbf{6 a}-\mathbf{h}, \mathbf{6 k}$}

To a solution of the appropriate $N$-tert-butylsulfonyl ketimine $\mathbf{1 a}-\mathbf{j}(0.10 \mathrm{mmol})$ and catalyst $5 \mathbf{g}(0.02 \mathrm{mmol})$ in THF $(1.5 \mathrm{~mL})$, allenoate $4 \mathbf{a}$ (or $\mathbf{4 b}$, for spiroazetidine $\mathbf{6 k}$ ) was added $(0.20 \mathrm{mmol})$. The mixture was stirred at room temperature and the conversion was monitored by TLC. The solvent was evaporated under reduced pressure and the crude was purified by FC, using $\mathrm{CH}_{2} \mathrm{Cl}_{2} / \mathrm{EtOAc} 9 / 1$ as eluent.

(S,E)-Ethyl-2-(1'-benzyl-1-(tert-butylsulfonyl)-2'-oxospiro[azetidine-2,3'-indolin]-4-ylidene)acetate

(6a). Pale orange foam; yield: 90\%. ${ }^{1} \mathrm{H}-\mathrm{NMR}\left(300 \mathrm{MHz}, \mathrm{CDCl}_{3}\right) \delta 7.50(\mathrm{~d}, \mathrm{br}, J=7.8 \mathrm{~Hz}, 1 \mathrm{H}), 7.19-7.38$ $(\mathrm{m}, 6 \mathrm{H}), 7.08(\mathrm{t}, \mathrm{br}, J=7.7 \mathrm{~Hz}, 1 \mathrm{H}), 6.69(\mathrm{~d}, \mathrm{br}, J=7.8 \mathrm{~Hz}, 1 \mathrm{H}), 5.68(\mathrm{~s}, \mathrm{br}, 1 \mathrm{H}), 5.04$ and $4.83(\mathrm{AB}$ system, $J=15.6 \mathrm{~Hz}, 2 \mathrm{H}), 4.16(\mathrm{q}, J=7.1 \mathrm{~Hz}, 2 \mathrm{H}), 3.71(\mathrm{dd}, J=15.6$ and $1.9 \mathrm{~Hz}, 1 \mathrm{H}), 3.44(\mathrm{dd}, J=15.6$ and $1.9 \mathrm{~Hz}, 1 \mathrm{H}), 1.33(\mathrm{~s}, 9 \mathrm{H}), 1.27(\mathrm{t}, J=7.1 \mathrm{~Hz}, 3 \mathrm{H}) ;{ }^{13} \mathrm{C}-\mathrm{NMR}\left(101 \mathrm{MHz}, \mathrm{CDCl}_{3}\right) \delta 173.3,167.3,159.2,143.6$, 134.6, 129.0 (3C), 128.2, 127.5 (2C), 126.4, 126.2, 124.6, 113.2, 94.3, 70.6, 59.7, 58.9, 44.4, 41.8, 22.7 (3C), 14.5; $[\alpha]_{25}^{\mathrm{D}}=+12.2\left(\right.$ c $0.90, \mathrm{CHCl}_{3}$ ); HRMS (ESI): $[\mathrm{M}+\mathrm{Na}]^{+}$, Calcd. for $\mathrm{C}_{25} \mathrm{H}_{28} \mathrm{~N}_{2} \mathrm{NaO}_{5} \mathrm{~S}^{+} 491.1611$, found 491.1604; enantiomeric ratio: 80:20, determined by HPLC (C-AD, Hexane/iPrOH 7:3, flow: $0.7 \mathrm{~mL} / \mathrm{min}, \lambda=254 \mathrm{~nm}$ ): $t_{\mathrm{R}}=16.80 \mathrm{~min}$ (major) $t_{\mathrm{R}}=23.38 \mathrm{~min}$ (minor).

(S,E)-Ethyl-2-(1-(tert-butylsulfonyl)-1'-methyl-2'-oxospiro[azetidine-2,3'-indolin]-4-ylidene)acetate

$(6 b)$. Pale orange foam; yield: 91\%. ${ }^{1} \mathrm{H}-\mathrm{NMR}\left(400 \mathrm{MHz}, \mathrm{CDCl}_{3}\right) \delta 7.50(\mathrm{~d}, J=7.5 \mathrm{~Hz}, 1 \mathrm{H}), 7.38(\mathrm{~d}, J=7.5 \mathrm{~Hz}$, $1 \mathrm{H}), 7.12(\mathrm{t}, J=7.5 \mathrm{~Hz}, 1 \mathrm{H}), 6.86(\mathrm{~d}, J=7.5 \mathrm{~Hz}, 1 \mathrm{H}), 5.66(\mathrm{t}, J=1.9 \mathrm{~Hz}, 1 \mathrm{H}), 4.16(\mathrm{q}, J=7.1 \mathrm{~Hz}, 2 \mathrm{H}), 3.66$ $(\mathrm{dd}, J=16.0,1.9 \mathrm{~Hz}, 1 \mathrm{H}), 3.41(\mathrm{dd}, J=16.0,1.9 \mathrm{~Hz}, 1 \mathrm{H}), 3.24(\mathrm{~s}, 3 \mathrm{H}), 1.32(\mathrm{~s}, 9 \mathrm{H}), 1.23-1.30(\mathrm{~m}, 3 \mathrm{H})$; ${ }^{13} \mathrm{C}-\mathrm{NMR}\left(101 \mathrm{MHz}, \mathrm{CDCl}_{3}\right) \delta 173.3,167.7,159.4,144.7,131.8,125.9,125.0,123.7,109.5,95.9,71.7$, 62.2, 60.5, 39.8, 27.3, $24.5(3 \mathrm{C}), 15.0 ;[\alpha]_{25}^{\mathrm{D}}=+19.3\left(c \mathrm{c} .80, \mathrm{CHCl}_{3}\right)$; HRMS (ESI): $[\mathrm{M}+\mathrm{Na}]^{+}$, Calcd. for $\mathrm{C}_{19} \mathrm{H}_{24} \mathrm{~N}_{2} \mathrm{NaO}_{5} \mathrm{~S}^{+}: 415.1298$, found 415.1303; enantiomeric ratio: 83:17, determined by HPLC (C-AD, Hexane/iPrOH 7:3, flow: $0.7 \mathrm{~mL} / \mathrm{min}, \lambda=254 \mathrm{~nm}$ ): $t_{R}=24.96 \mathrm{~min}$ (major) $t_{\mathrm{R}}=29.58 \mathrm{~min}$ (minor).

(S,E)-Ethyl-2-(1-(tert-butylsulfonyl)-2'-oxo-1'-tritylspiro[azetidine-2,3'-indolin]-4-ylidene)acetate

$(6 c)$. Pale orange foam; yield: 95\%. ${ }^{1} \mathrm{H}-\mathrm{NMR}\left(300 \mathrm{MHz}, \mathrm{CDCl}_{3}\right) \delta 7.50-7.39(\mathrm{~m}, 7 \mathrm{H}), 7.30-7.16(\mathrm{~m}, 9 \mathrm{H})$, $7.03-6.89(\mathrm{~m}, 2 \mathrm{H}), 6.28(\mathrm{~d}, J=7.4 \mathrm{~Hz}, 1 \mathrm{H}), 5.62(\mathrm{t}, J=1.9 \mathrm{~Hz}, 1 \mathrm{H}), 4.19-4.05(\mathrm{~m}, 2 \mathrm{H}), 3.58(\mathrm{dd}, J=15.7$, $1.9 \mathrm{~Hz}, 1 \mathrm{H}), 3.31(\mathrm{dd}, J=15.7,1.9 \mathrm{~Hz}, 1 \mathrm{H}), 1.34(\mathrm{~s}, 9 \mathrm{H}), 1.24(\mathrm{t}, J=6.8 \mathrm{~Hz}, 3 \mathrm{H}) ;{ }^{13} \mathrm{C}-\mathrm{NMR}(75 \mathrm{MHz}$, $\mathrm{CDCl}_{3}$ ) $\delta 172.9,167.2,9.0,144.0,141.7$ (3C), 129.5 (7C), 127.7 (6C), 127.1 (3C), 125.6, 123.9, 122.6, 116.6, 94.9, 74.9, 71.6, 61.7, 59.8, 40.1, $24.1(3 \mathrm{C}), 14.4 ;[\alpha]_{25}^{\mathrm{D}}=-0.67$ (c 1.5, $\left.\mathrm{CHCl}_{3}\right)$; HRMS (ESI): [M + Na $]^{+}$, Calcd. for $\mathrm{C}_{37} \mathrm{H}_{36} \mathrm{~N}_{2} \mathrm{NaO}_{5} \mathrm{~S}^{+}$: 643.2237, found 643.2240; enantiomeric ratio: 71:29, determined by HPLC (C-AD, Hexane/iPrOH 7:3, flow: $0.7 \mathrm{~mL} / \mathrm{min}, \lambda=254 \mathrm{~nm}$ ): $t_{\mathrm{R}}=8.00 \mathrm{~min}$ (major) $t_{\mathrm{R}}=11.84 \mathrm{~min}$ (minor).

(S,E)-Ethyl-2-(1-(tert-butylsulfonyl)-2'-oxo-1'-propylspiro[azetidine-2,3'-indolin]-4-ylidene)acetate $\quad$ (6d). Pale orange foam; yield: 77\%. ${ }^{1} \mathrm{H}-\mathrm{NMR}\left(300 \mathrm{MHz}, \mathrm{CDCl}_{3}\right) \delta 7.49(\mathrm{~d}, J=7.4 \mathrm{~Hz}, 1 \mathrm{H}), 7.35(\mathrm{td}, J=7.4$ and $1.1 \mathrm{~Hz}, 1 \mathrm{H}), 7.10(\mathrm{t}, J=7.4 \mathrm{~Hz}, 1 \mathrm{H}), 6.86(\mathrm{~d}, J=7.4 \mathrm{~Hz}, 1 \mathrm{H}), 5.65(\mathrm{t}, J=1.9 \mathrm{~Hz}, 1 \mathrm{H}), 4.15(\mathrm{q}, J=7.1 \mathrm{~Hz}$, $2 \mathrm{H}), 3.75(\mathrm{dt}, J=14.6$ and $6.8 \mathrm{~Hz}, 1 \mathrm{H}), 3.63(\mathrm{dd}, J=15.6$ and $1.9 \mathrm{~Hz}, 1 \mathrm{H}), 3.58(\mathrm{dt}, J=14.6$ and $6.8 \mathrm{~Hz}$, $1 \mathrm{H}), 3.39(\mathrm{dd}, J=15.6$ and $1.9 \mathrm{~Hz}, 1 \mathrm{H}), 1.72(\mathrm{sext}, J=6.8 \mathrm{~Hz}, 2 \mathrm{H}), 1.32(\mathrm{~s}, 9 \mathrm{H}), 1.27-1.22(\mathrm{~m}, 3 \mathrm{H})$ $0.97(\mathrm{t}, J=6.8 \mathrm{~Hz}, 3 \mathrm{H}) ;{ }^{13} \mathrm{C}-\mathrm{NMR}\left(101 \mathrm{MHz}, \mathrm{CDCl}_{3}\right) \delta 173.1,167.8,159.6,142.9,131.6,126.2,125.1$, 
$123.5,109.8,95.7,71.8,60.5,42.7,40.0,30.4,24.6(3 \mathrm{C}), 21.2,15.1,12.0 ;[\alpha]_{25}^{\mathrm{D}}=+5.5\left(c 1.02, \mathrm{CHCl}_{3}\right)$; HRMS (ESI) calculated for $\mathrm{C}_{21} \mathrm{H}_{28} \mathrm{~N}_{2} \mathrm{NaO}_{5} \mathrm{~S}^{+}[\mathrm{M}+\mathrm{Na}]^{+} 443.1611$, found 443.1617; enantiomeric ratio: 78:22, determined by HPLC (C-AD, Hexane/iPrOH 7:3, flow: $0.7 \mathrm{~mL} / \mathrm{min}, \lambda=254 \mathrm{~nm}$ ): $t_{\mathrm{R}}=7.73 \mathrm{~min}$ (major) $t_{\mathrm{R}}=9.85 \mathrm{~min}$ (minor).

(S,E)-Ethyl-2-(1-(tert-butylsulfonyl)-1'-isopropyl-2'-oxospiro[azetidine-2,3'-indolin]-4-ylidene)acetate (6e). Pale orange foam; yield: $93 \% .{ }^{1} \mathrm{H}-\mathrm{NMR}\left(300 \mathrm{MHz}, \mathrm{CDCl}_{3}\right) \delta 7.49(\mathrm{~d}, J=7.7 \mathrm{~Hz}, 1 \mathrm{H}), 7.34(\mathrm{t}, J=7.7 \mathrm{~Hz}$, $1 \mathrm{H}), 7.08(\mathrm{t}, J=7.7 \mathrm{~Hz}, 1 \mathrm{H}), 6.99(\mathrm{~d}, J=7.7 \mathrm{~Hz}, 1 \mathrm{H}), 5.64(\mathrm{t}, J=2.0 \mathrm{~Hz}, 1 \mathrm{H}), 4.56($ hept $, J=6.8 \mathrm{~Hz}, 1 \mathrm{H}), 4.15$ $(\mathrm{q}, J=7.6 \mathrm{~Hz}, 2 \mathrm{H}), 3.64(\mathrm{dd}, J=15.9$ and $2.0 \mathrm{~Hz}, 1 \mathrm{H}), 3.40(\mathrm{dd}, J=15.9,2.0 \mathrm{~Hz}, 1 \mathrm{H}), 1.50(\mathrm{~d}, J=6.8 \mathrm{~Hz}$, $3 \mathrm{H}), 1.48(\mathrm{~d}, J=6.8 \mathrm{~Hz}, 3 \mathrm{H}), 1.30(\mathrm{~s}, 9 \mathrm{H}), 1.26(\mathrm{t}, J=7.6 \mathrm{~Hz}, 3 \mathrm{H}) ;{ }^{13} \mathrm{C}-\mathrm{NMR}\left(101 \mathrm{MHz}, \mathrm{CDCl}_{3}\right) \delta 172.4$, 167.2, 159.1, 143.2, 130.9, 125.6, 124.8, 122.5, 110.4, 95.0, 71.1, 61.5, 59.9, 44.7, 39.1, 23.9 (3C), 19.2 (2C), 14.5; $[\alpha]_{25}^{\mathrm{D}}=+14.7\left(\right.$ c 0.99, $\left.\mathrm{CHCl}_{3}\right)$; HRMS (ESI) calculated for $\mathrm{C}_{21} \mathrm{H}_{28} \mathrm{~N}_{2} \mathrm{NaO}_{5} \mathrm{~S}^{+}[\mathrm{M}+\mathrm{Na}]^{+} 443.1611$, found 443.1616; enantiomeric ratio 82:18, determined by HPLC (C-AD, Hexane/iPrOH 7:3, flow: $0.7 \mathrm{~mL} / \mathrm{min}, \lambda=254 \mathrm{~nm}$ ): $t_{\mathrm{R}}=7.32 \mathrm{~min}$ (major) $t_{\mathrm{R}}=9.33 \mathrm{~min}$ (minor).

(S,E)-Ethyl-2-(1-(tert-butylsulfonyl)-2'-oxo-1'-phenylspiro[azetidine-2,3'-indolin]-4-ylidene)acetate (6f). Pale orange foam; yield: $82 \% .{ }^{1} \mathrm{H}-\mathrm{NMR}\left(300 \mathrm{MHz}, \mathrm{CDCl}_{3}\right) \delta 7.64-7.39(\mathrm{~m}, 6 \mathrm{H}), 7.30(\mathrm{t}, J=7.8 \mathrm{~Hz}$, $1 \mathrm{H}), 7.15(\mathrm{t}, J=7.8 \mathrm{~Hz}, 1 \mathrm{H}), 6.83(\mathrm{~d}, J=7.8 \mathrm{~Hz}, 1 \mathrm{H}), 5.68(\mathrm{t}, J=2.0 \mathrm{~Hz}, 1 \mathrm{H}), 4.17(\mathrm{q}, J=7.2 \mathrm{~Hz}, 2 \mathrm{H})$, $3.77(\mathrm{dd}, J=16.0,2.0 \mathrm{~Hz}, 1 \mathrm{H}), 3.52(\mathrm{dd}, J=16.0,2.0 \mathrm{~Hz}, 1 \mathrm{H}), 1.33(\mathrm{~s}, 9 \mathrm{H}), 1.27(\mathrm{t}, J=7.2 \mathrm{~Hz}, 3 \mathrm{H})$; ${ }^{13} \mathrm{C}-\mathrm{NMR}\left(101 \mathrm{MHz}, \mathrm{CDCl}_{3}\right) \delta$ 172.3, 167.2, 158.9, 144.6, 134.0, 131.2, 129.8 (2C), 128.5, 126.6 (2C), 125.8, $124.9,123.5,110.2,95.4,71.3,61.6,60.0,39.2,24.0(3 \mathrm{C}), 14.5 ;[\alpha]_{25}^{\mathrm{D}}=+10.3$ (c 1.04, $\mathrm{CHCl}_{3}$ ); HRMS (ESI) calculated for $\mathrm{C}_{24} \mathrm{H}_{26} \mathrm{~N}_{2} \mathrm{NaO}_{5} \mathrm{~S}^{+}[\mathrm{M}+\mathrm{Na}]^{+} 477.1455$, found 447.1460; enantiomeric ratio: 77:23, determined by HPLC (C-AD, Hexane/iPrOH 4:1, flow: $0.7 \mathrm{~mL} / \mathrm{min}, \lambda=254 \mathrm{~nm}$ ): $t_{\mathrm{R}}=9.63 \mathrm{~min}$ (major) $t_{\mathrm{R}}=14.79 \mathrm{~min}$ (minor).

(S,E)-Ethyl-2-(1'-benzyl-1-(tert-butylsulfonyl)-5'-methoxy-2'-oxospiro[azetidine-2,3'-indolin]-4-ylidene)-acetate (6g). Pale orange foam; yield: $89 \% .{ }^{1} \mathrm{H}-\mathrm{NMR}\left(400 \mathrm{MHz}, \mathrm{CDCl}_{3}\right) \delta 7.38-7.27(\mathrm{~m}, 5 \mathrm{H}), 7.12(\mathrm{~d}, J=2.7 \mathrm{~Hz}$, $1 \mathrm{H}), 6.78(\mathrm{dd}, J=8.4$ and $2.7 \mathrm{~Hz}, 1 \mathrm{H}), 6.60(\mathrm{~d}, J=8.4 \mathrm{~Hz}, 1 \mathrm{H}), 5.71(\mathrm{t}, J=1.9 \mathrm{~Hz}, 1 \mathrm{H}), 5.05$ and 4.81 (AB system, $J=15.8 \mathrm{~Hz}, 2 \mathrm{H}), 4.19(\mathrm{q}, J=7.2 \mathrm{~Hz}, 2 \mathrm{H}), 3.78(\mathrm{~s}, 3 \mathrm{H}), 3.75(\mathrm{dd}, J=15.9$ and $1.9 \mathrm{~Hz}, 1 \mathrm{H})$, $3.45(\mathrm{dd}, J=15.9$ and $1.9 \mathrm{~Hz}, 1 \mathrm{H}), 1.38(\mathrm{~s}, 9 \mathrm{H}), 1.30(\mathrm{t}, J=7.2 \mathrm{~Hz}, 3 \mathrm{H}) ;{ }^{13} \mathrm{C}-\mathrm{NMR}\left(101 \mathrm{MHz}, \mathrm{CDCl}_{3}\right)$ $\delta$ 172.5, 167.1, 158.8, 156.4, 136.4, 135.2, 128.8 (2C), 127.7, 127.3 (2C), 127.0, 115.4, 111.4, 110.5, 95.2, $71.5,61.8,59.9,55.9,44.3,39.7,24.0(3 \mathrm{C}), 14.4 ;[\alpha]_{25}^{\mathrm{D}}=+8.9\left(c 0.95, \mathrm{CHCl}_{3}\right)$; HRMS (ESI) calculated for $\mathrm{C}_{26} \mathrm{H}_{30} \mathrm{~N}_{2} \mathrm{NaO}_{5} \mathrm{~S}^{+}[\mathrm{M}+\mathrm{Na}]^{+}$521.1717, found 521.1720; enantiomeric ratio: 76:24, determined by HPLC (C-AD, Hexane/iPrOH 4:1, flow: $0.7 \mathrm{~mL} / \mathrm{min}, \lambda=254 \mathrm{~nm}$ ): $t_{\mathrm{R}}=15.00 \mathrm{~min}$ (major) $t_{\mathrm{R}}=20.63$ $\min$ (minor).

(S,E)-Ethyl-2-(1'-benzyl-1-(tert-butylsulfonyl)-5'-chloro-2'-oxospiro[azetidine-2,3'-indolin]-4-ylidene)-acetate (6h). Pale orange foam; yield: $26 \% .{ }^{1} \mathrm{H}-\mathrm{NMR}\left(400 \mathrm{MHz}, \mathrm{CDCl}_{3}\right) \delta 7.52(\mathrm{~d}, J=2.1 \mathrm{~Hz}, 1 \mathrm{H}), 7.38-7.26$ $(\mathrm{m}, 5 \mathrm{H}), 7.23(\mathrm{dd}, J=8.2$ and $2.1 \mathrm{~Hz}, 1 \mathrm{H}), 6.63(\mathrm{~d}, J=8.2 \mathrm{~Hz}, 1 \mathrm{H}), 5.71(\mathrm{t}, J=2.1 \mathrm{~Hz}, 1 \mathrm{H}), 5.07$ and 4.82 (AB system, $J=16.0 \mathrm{~Hz}, 2 \mathrm{H}), 4.20(\mathrm{q}, J=7.1 \mathrm{~Hz}, 2 \mathrm{H}), 3.74(\mathrm{dd}, J=15.9$ and $2.1 \mathrm{~Hz}, 1 \mathrm{H}), 3.47(\mathrm{dd}, J=15.9$ and $2.1 \mathrm{~Hz}, 1 \mathrm{H}), 1.39(\mathrm{~s}, 9 \mathrm{H}), 1.31(\mathrm{t}, J=7.1 \mathrm{~Hz}, 3 \mathrm{H}) ;{ }^{13} \mathrm{C}-\mathrm{NMR}\left(101 \mathrm{MHz}, \mathrm{CDCl}_{3}\right) \delta 172.4,166.9,158.2$, 141.6, 136.7, 134.6, 130.8, 129.0 (2C), 128.7, 127.9, 127.2 (2C), 124.7, 111.0, 95.6, 70.7, 61.8, 60.0, 44.4, 39.5, $23.9(3 \mathrm{C}), 14.4 ;[\alpha]_{25}^{\mathrm{D}}=+9.8\left(c 1.05, \mathrm{CHCl}_{3}\right)$; HRMS (ESI) calculated for $\mathrm{C}_{25} \mathrm{H}_{27} \mathrm{ClN}_{2} \mathrm{NaO}_{5} \mathrm{~S}^{+}[\mathrm{M}+\mathrm{Na}]^{+}$ 525.1221, found 525.1229; enantiomeric ratio: 72:28, determined by HPLC (C-AD, Hexane/iPrOH 4:1, flow: $0.7 \mathrm{~mL} / \mathrm{min}, \lambda=254 \mathrm{~nm}$ ): $t_{\mathrm{R}}=10.31 \mathrm{~min}$ (major) $t_{\mathrm{R}}=16.59$ (minor).

(S,E)-Benzyl-2-(1'-benzyl-1-(tert-butylsulfonyl)-2'-oxospiro[azetidine-2,3'-indolin]-4-ylidene)acetate (6k). Pale yellow foam; yield: 80\%. ${ }^{1} \mathrm{H}-\mathrm{NMR}\left(400 \mathrm{MHz}, \mathrm{CDCl}_{3}\right) \delta 7.53(\mathrm{~d}, \mathrm{br}, J=7.8 \mathrm{~Hz}, 1 \mathrm{H}), 7.44-7.23$ $(\mathrm{m}, 11 \mathrm{H}), 7.11(\mathrm{t}, \mathrm{br}, J=7.7 \mathrm{~Hz}, 1 \mathrm{H}), 6.72(\mathrm{~d}, \mathrm{br}, J=7.8 \mathrm{~Hz}, 1 \mathrm{H}), 5.78(\mathrm{~s}, \mathrm{br}, 1 \mathrm{H}), 5.19(\mathrm{~s}, \mathrm{br}, 2 \mathrm{H}), 5.08$ and $4.84(\mathrm{AB}$ system, $J=15.8 \mathrm{~Hz}, 2 \mathrm{H}), 3.74(\mathrm{~d}, \mathrm{br}, J=16.0 \mathrm{~Hz}, 1 \mathrm{H}), 3.47(\mathrm{~d}, \mathrm{br}, J=16.0 \mathrm{~Hz}, 1 \mathrm{H})$, 1.36 (s, 9H); ${ }^{13} \mathrm{C}-\mathrm{NMR}\left(101 \mathrm{MHz}, \mathrm{CDCl}_{3}\right) \delta 173.4,167.5,160.0,143.9,136.9,135.7,131.7,129.5(3 \mathrm{C})$, 129.3, 129.0, 128.8, 128.4, 128.0 (3C), 126.0, 125.1, 123.8, 110.7, 95.5, 71.8, 66.6, 62.3, 44.9, 40.3, 24.6 (3C); $[\alpha]_{25}^{\mathrm{D}}=+15.0\left(\right.$ c $\left.0.8, \mathrm{CHCl}_{3}\right)$; HRMS (ESI): $[\mathrm{M}+\mathrm{Na}]^{+}$, Calcd. for $\mathrm{C}_{30} \mathrm{H}_{30} \mathrm{~N}_{2} \mathrm{NaO}_{5} \mathrm{~S}^{+} 553.1768$, 
found 553.1772; enantiomeric ratio: 78:22, determined by HPLC (C-AD, Hexane/iPrOH 7:3, flow: $0.7 \mathrm{~mL} / \mathrm{min}, \lambda=254 \mathrm{~nm}$ ): $t_{\mathrm{R}}=16.80 \mathrm{~min}$ (major) $t_{\mathrm{R}}=23.38 \mathrm{~min}$ (minor).

\subsubsection{Reactions of $6 a$}

(S,E)-2-(1'-Benzyl-1-(tert-butylsulfonyl)-2'-oxospiro[azetidine-2,3'-indolin]-4-ylidene)acetic acid (7). To a solution of $6 \mathbf{a}(0.21 \mathrm{mmol})$ in water/THF/iPrOH $(1: 1: 1,1.5 \mathrm{~mL}), \mathrm{LiOH}(0.63 \mathrm{mmol})$ was added and the mixture was stirred at room temperature. After the completion of the reaction (monitored by TLC), the reaction mixture was quenched with a $1 \mathrm{M}$ aqueous solution of $\mathrm{HCl}$ and extracted with $\mathrm{CH}_{2} \mathrm{Cl}_{2}$. The organic layer was collected, dried over anhydrous sodium sulfate, and concentrated under reduced pressure affording the product as a white foam (quantitative yield). ${ }^{1} \mathrm{H}-\mathrm{NMR}\left(400 \mathrm{MHz}, \mathrm{CDCl}_{3}\right) \delta 7.54$ $(\mathrm{d}, J=7.4 \mathrm{~Hz}, 1 \mathrm{H}), 7.41-7.23(\mathrm{~m}, 6 \mathrm{H}), 7.12(\mathrm{t}, J=7.4 \mathrm{~Hz}, 1 \mathrm{H}), 6.73(\mathrm{~d}, J=7.4 \mathrm{~Hz}, 1 \mathrm{H}), 5.71(\mathrm{t}, J=1.9 \mathrm{~Hz}$, $1 \mathrm{H}), 5.07$ and $4.87(\mathrm{AB}$ system, $J=15.8 \mathrm{~Hz}, 2 \mathrm{H}), 3.76(\mathrm{dd}, J=16.3$ and $2.0 \mathrm{~Hz}, 1 \mathrm{H}), 3.49(\mathrm{dd}, J=16.3$ and $2.0 \mathrm{~Hz}, 1 \mathrm{H}), 2.05(\mathrm{~m}, \mathrm{br}, 1 \mathrm{H}), 1.37(\mathrm{~s}, 9 \mathrm{H}) ;{ }^{13} \mathrm{C}-\mathrm{NMR}\left(101 \mathrm{MHz}, \mathrm{CDCl}_{3}\right) \delta$ 172.6, 172.5, 161.3, 143.2, 135.0, 131.1, 128.9 (2C), 127.8, 127.3 (2C), 125.1, 124.4, 123.2, 110.1, 94.4, 71.2, 61.8, 44.3, 39.7, 23.9 (3C); $[\alpha]_{25}^{\mathrm{D}}=+5.7\left(c 0.79, \mathrm{CHCl}_{3}\right)$; HRMS (ESI) calculated for $\mathrm{C}_{23} \mathrm{H}_{24} \mathrm{~N}_{2} \mathrm{NaO}_{5} \mathrm{~S}^{+}[\mathrm{M}+\mathrm{Na}]^{+} 463.1298$, found 463.1289 .

(S)-Ethyl-1-benzyl-1'-(tert-butylsulfonyl)-2-oxo-1', 3'-dihydrospiro[indoline-3,2'-pyrrole]-4'-carboxylate (8). To a stirred solution of $6 \mathrm{a}(0.21 \mathrm{mmol})$ in $\mathrm{CH}_{2} \mathrm{Cl}_{2}(9 \mathrm{~mL})$ at $0{ }^{\circ} \mathrm{C}_{,} \mathrm{CF}_{3} \mathrm{SO}_{3} \mathrm{H}(0.68 \mathrm{mmol})$ was added. After stirring at $0{ }^{\circ} \mathrm{C}$ for $2 \mathrm{~h}$, the mixture was neutralized with $0.1 \mathrm{M} \mathrm{NaOH}$ and extracted with $\mathrm{CH}_{2} \mathrm{Cl}_{2}(4 \times 15 \mathrm{~mL})$. The combined organic phases were dried $\left(\mathrm{MgSO}_{4}\right)$ and concentrated in vacuo, affording the product as a white foam (quantitative yield). ${ }^{1} \mathrm{H}-\mathrm{NMR}\left(400 \mathrm{MHz}, \mathrm{CDCl}_{3}\right) \delta 7.56(\mathrm{~d}, \mathrm{br}$, $J=7.8 \mathrm{~Hz}, 1 \mathrm{H}), 7.40-7.25(\mathrm{~m}, 6 \mathrm{H}), 7.05(\mathrm{t}, \mathrm{br}, J=7.7 \mathrm{~Hz}, 1 \mathrm{H}), 6.79(\mathrm{~d}, \mathrm{br}, J=7.8 \mathrm{~Hz}, 1 \mathrm{H}), 6.15(\mathrm{~s}, \mathrm{br}$, $1 \mathrm{H}), 4.97$ and $4.91(\mathrm{AB}$ system, $J=15.5 \mathrm{~Hz}, 2 \mathrm{H}), 4.23(\mathrm{q}, J=7.1 \mathrm{~Hz}, 2 \mathrm{H}), 3.49(\mathrm{~d}, \mathrm{br}, J=16.4 \mathrm{~Hz}, 1 \mathrm{H})$, $2.63(\mathrm{~d}, \mathrm{br}, J=16.4 \mathrm{~Hz}, 1 \mathrm{H}), 1.46(\mathrm{~s}, 9 \mathrm{H}), 1.38(\mathrm{t}, J=7.1 \mathrm{~Hz}, 3 \mathrm{H}) ;{ }^{13} \mathrm{C}-\mathrm{NMR}\left(101 \mathrm{MHz}, \mathrm{CDCl}_{3}\right) \delta 171.1$, 170.5, 169.7, 142.3, 134.7, 131.6, 129.1 (2C), 128.1, 127.3 (2C), 126.4, 125.1, 124.0, 81.2, 79.7, 66.6, 58.5, 44.2, 38.4, $24.0(3 \mathrm{C}), 14.2 ;[\alpha]_{25}^{\mathrm{D}}=+6.3\left(\right.$ c $\left.0.53, \mathrm{CHCl}_{3}\right)$; HRMS (ESI): $[\mathrm{M}+\mathrm{Na}]^{+}$, Calcd. for $\mathrm{C}_{25} \mathrm{H}_{28} \mathrm{~N}_{2} \mathrm{NaO}_{5} \mathrm{~S}^{+}$ 491.1611, found 491.1617 .

(S)-Ethyl-4-(1-benzyl-3-(tert-butylsulfonamido)-2-oxoindolin-3-yl)-3-oxobutanoate (9). To a solution of 6a $(0.20 \mathrm{mmol})$ in trifluoroacetic acid $(5 \mathrm{~mL})$ and $\mathrm{CH}_{2} \mathrm{Cl}_{2}(2 \mathrm{~mL})$, anisole $(4 \mathrm{mmol})$ was added, and the mixture was stirred for $1 \mathrm{~h}$ at $60^{\circ} \mathrm{C}$. To this saturated $\mathrm{Na}_{2} \mathrm{CO}_{3}$ was added and organic materials were extracted with EtOAc. Dried and concentrated extract was subjected to FC (Hexane/EtOAc 1/1) to give the product as a pale yellow foam (yield: $65 \%) .{ }^{1} \mathrm{H}-\mathrm{NMR}\left(400 \mathrm{MHz}, \mathrm{CDCl}_{3}\right) \delta 7.57(\mathrm{~d}, \mathrm{br}, J=7.8 \mathrm{~Hz}$, $1 \mathrm{H}), 7.43-7.24(\mathrm{~m}, 5 \mathrm{H}), 7.21(\mathrm{t}, \mathrm{br}, J=7.7 \mathrm{~Hz}, 1 \mathrm{H}), 7.04(\mathrm{t}, J=7.7 \mathrm{~Hz}, 1 \mathrm{H}), 6.72(\mathrm{~d}, \mathrm{br}, J=7.8 \mathrm{~Hz}, 1 \mathrm{H})$, $5.75(\mathrm{~s}, \mathrm{br}, 1 \mathrm{H}), 5.00$ and $4.95(\mathrm{AB}$ system, $J=16.0 \mathrm{~Hz}, 2 \mathrm{H}), 4.15(\mathrm{q}, J=7.1 \mathrm{~Hz}, 2 \mathrm{H}), 3.60(\mathrm{~d}, J=17.4 \mathrm{~Hz}$, $1 \mathrm{H}), 3.45$ and $3.40(\mathrm{AB}$ system, $J=16.0 \mathrm{~Hz}, 2 \mathrm{H}), 3.07(\mathrm{~d}, J=17.4 \mathrm{~Hz}, 1 \mathrm{H}), 1.34(\mathrm{~s}, 9 \mathrm{H}), 1.22(\mathrm{t}, J=7.1 \mathrm{~Hz}$, 3H); ${ }^{13} \mathrm{C}-\mathrm{NMR}\left(101 \mathrm{MHz}, \mathrm{CDCl}_{3}\right) \delta 201.0,174.7,166.1,142.4,135.6,129.7,128.8(2 \mathrm{C}), 128.7,127.7,127.3$ (2C), 125.3, 122.9, 109.7, 61.7, 60.6, 60.3, 50.1, 49.2, 44.4, $24.1(3 \mathrm{C}), 14.0 ;[\alpha]_{25}^{\mathrm{D}}=-57.4\left(\mathrm{c} 0.50, \mathrm{CHCl}_{3}\right)$; HRMS (ESI): [M + Na] $]^{+}$, Calcd. for $\mathrm{C}_{25} \mathrm{H}_{30} \mathrm{~N}_{2} \mathrm{NaO}_{6} \mathrm{~S}^{+} 509.1717$, found 509.1711.

Supplementary Materials: The following are available online, NMR spectra of all new compounds and HPLC chromatograms of spiroazetidines $\mathbf{6 a}-\mathbf{k}$.

Author Contributions: For research articles with several authors, a short paragraph specifying their individual contributions must be provided. The following statements should be used "G.R. and A.S. conceived and designed the experiments; M.F. and C.S. performed the experiments; G.L. analyzed the data and contributed reagents/materials/analysis tools; G.R. and A.S. wrote the paper". Authorship must be limited to those who have contributed substantially to the work reported.

Conflicts of Interest: The authors declare no conflict of interest. 


\section{References}

1. Zheng, Y.-J.; Tice, C.M. The utilization of spirocyclic scaffolds in novel drug discovery. Expert Opin. Drug Discov. 2016, 11, 831-834. [CrossRef] [PubMed]

2. Zheng, Y.; Tice, C.M.; Singh, S.B. The use of spirocyclic scaffolds in drug discovery. Bioorg. Med. Chem. Lett. 2014, 24, 3673-3682. [CrossRef] [PubMed]

3. Yu, B.; Yu, D.-Q.; Liu, H.-M. Spirooxindoles: Promising scaffolds for anticancer agents. Eur. J. Med. Chem. 2015, 97, 673-698. [CrossRef] [PubMed]

4. Liu, J.; Sun, Y.; Zhang, X.; Liang, X.; Wu, Y.; Wang, Y.; Jiang, X. Spirooxindoles, a potential novel class of anti-inflammatory agents. Inflamm. Cell Signal. 2014, 1, e372. [CrossRef]

5. Ye, N.; Chen, H.; Wold, E.A.; Shi, P.-Y.; Zhou, J. Therapeutic Potential of Spirooxindoles as Antiviral Agents. ACS Infect. Dis. 2016, 2, 382-392. [CrossRef] [PubMed]

6. Singh, G.S.; Desta, Z.Y. Isatins As Privileged Molecules in Design and Synthesis of Spiro-Fused Cyclic Frameworks. Chem. Rev. 2012, 112, 6104-6155. [CrossRef] [PubMed]

7. Franz, A.K.; Hanhan, N.V.; Ball-Jones, N.R. Asymmetric Catalysis for the Synthesis of Spirocyclic Compounds. ACS Catal. 2013, 3, 540-553. [CrossRef]

8. Mei, G.-J.; Li, D.; Zhou, G.-X.; Shi, Q.; Cao, Z.; Shi, F. A catalytic asymmetric construction of a tetrahydroquinoline-based spirooxindole framework via a diastereo- and enantioselective decarboxylative [4 + 2] cycloaddition. Chem. Commun. 2017, 53, 10030-10033. [CrossRef] [PubMed]

9. Orr, S.T.M.; Beveridge, R.; Bhattacharya, S.K.; Cameron, K.O.; Coffey, S.; Fernando, D.; Hepworth, D.; Jackson, M.V.; Khot, V.; Kosa, R.; et al. Evaluation and Synthesis of Polar Aryl- and Heteroaryl Spiroazetidine-Piperidine Acetamides as Ghrelin Inverse Agonists. ACS Med. Chem. Lett. 2015, 6, $156-161$. [CrossRef] [PubMed]

10. Lüthy, M.; Wheldon, M.C.; Haji-Cheteh, C.; Atobe, M.; Bond, P.S.; O’Brien, P.; Hubbard, R.E.; Fairlamb, I.J.S. Lead-oriented synthesis: Investigation of organolithium-mediated routes to 3-D scaffolds and 3-D shape analysis of a virtual lead-like library. Bioorg. Med. Chem. 2015, 23, 2680-2694. [CrossRef] [PubMed]

11. Stucchi, M.; Lesma, G.; Meneghetti, F.; Rainoldi, G.; Sacchetti, A.; Silvani, A. Organocatalytic Asymmetric Biginelli-like Reaction Involving Isatin. J. Org. Chem. 2016, 81, 1877-1884. [CrossRef] [PubMed]

12. Lesma, G.; Landoni, N.; Sacchetti, A.; Silvani, A. The spiropiperidine-3,30-oxindole scaffold: A type II $\beta$-turn peptide isostere. Tetrahedron 2010, 66, 4474-4478. [CrossRef]

13. Rainoldi, G.; Faltracco, M.; Lo Presti, L.; Silvani, A.; Lesma, G. Highly diastereoselective entry into chiral spirooxindole-based 4-methyleneazetidines via formal [2+2] annulation reaction. Chem. Commun. 2016, 52, 11575-11578. [CrossRef] [PubMed]

14. Cheng, D.; Ishihara, Y.; Tan, B.; Barbas, C.F., III. Organocatalytic Asymmetric Assembly Reactions: Synthesis of Spirooxindoles via Organocascade Strategies. ACS Catal. 2014, 4, 743-762. [CrossRef]

15. Chauhan, P.; Chimni, S.S. Organocatalytic asymmetric synthesis of 3-amino-2-oxindole derivatives bearing a tetra-substituted stereocenter. Tetrahedron Asymmetry 2013, 24, 343-356. [CrossRef]

16. Yu, J.-S.; Zhou, F.; Liu, Y.-L.; Zhou, J. A Journey in the Catalytic Synthesis of 3-Substituted 3-Amino-oxindoles. Synlett 2015, 26, 2491-2504. [CrossRef]

17. Denis, J.-B.; Masson, G.; Retailleau, P.; Zhu, J. Cinchona Alkaloid Amide Catalyzed Enantioselective Formal [2 + 2] Cycloadditions of Allenoates and Imines: Synthesis of 2,4-Disubstituted Azetidines. Angew. Chem. Int. Ed. 2011, 50, 5356-5360. [CrossRef] [PubMed]

18. Takizawa, S.; Arteaga Arteaga, F.; Yoshida, Y.; Suzuki, M.; Sasai, H. Organocatalyzed Formal [2 + 2] Cycloaddition of Ketimines with Allenoates: Facile Access to Azetidines with a Chiral Tetrasubstituted Carbon Stereogenic Center. Org. Lett. 2013, 15, 4142-4145. [CrossRef] [PubMed]

19. He, Q.; Wu, L.; Kou, X.; Butt, N.; Yang, G.; Zhang, W. Pd(II)-Catalyzed Asymmetric Addition of Arylboronic Acids to Isatin-Derived Ketimines. Org. Lett. 2016, 18, 288-291. [CrossRef] [PubMed]

20. Sun, P.; Weinreb, S.M. tert-Butylsulfonyl (Bus), a New Protecting Group for Amines. J. Org. Chem. 1997, 62, 8604-8608. [CrossRef] [PubMed]

Sample Availability: Not available. 
(C) 2017 by the authors. Licensee MDPI, Basel, Switzerland. This article is an open access article distributed under the terms and conditions of the Creative Commons Attribution (CC BY) license (http:/ / creativecommons.org/licenses/by/4.0/). 